\title{
Sprawozdanie
}

\section{Międzynarodowa konferencja naukowa Edukacja prawnicza we wspót- czesnej Europie, Zielona Góra, 30 września-2 października 2014 r.}

W dniach od 30 września do 2 października 2014 r. w Zielonej Górze odbyła się międzynarodowa konferencja naukowa pt. Edukacja prawnicza we wspótczesnej Europie. Jej organizatorem był nowo powstały Wydział Prawa i Administracji, który chciał w ten sposób zainaugurować swoją działalność naukową w łonie Uniwersytetu Zielonogórskiego.

O aktualności problematyki edukacji prawniczej we współczesnej, znoszącej kolejne bariery i przemieszanej migracjami Europie nikogo nie trzeba przekonywać. Pytania dotychczas zadawane w skali krajowej (np. jak kształcić prawników? jak przekazywać wiedzę o prawie i budować właściwą, świadomą postawę obywatelską? jak łączyć kształcenie akademickie z wymogami współczesnego rynku pracy?) zyskały szerszy, ponadnarodowy wymiar. Celem konferencji była próba znalezienia odpowiedzi przynajmniej na część z pojawiających się w tym obszarze pytań, wymiana doświadczeń dotyczących modeli kształcenia prawników w wybranych państwach europejskich oraz próba komparatystycznego spojrzenia na zagadnienie edukacji prawniczej, które z jednej strony stanowi szalenie wdzięczny przedmiot badań, a z drugiej strony - ze względu na skalę trudności - jest zagadnieniem stosunkowo rzadko podejmowanym.

Honorowy patronat nad konferencją objęli: JM rektor Uniwersytetu Zielonogórskiego prof. dr hab. inż. Tadeusz Kuczyński, pierwsza prezes Sądu 
Najwyższego prof. dr hab. Małgorzata Gersdorf, prezydent miasta Zielona Góra Janusz Kubicki.

Konferencję otworzył prof. dr hab. Bogusław Banaszak (Dziekan Wydziału Prawa i Administracji UZ), który powitał przybyłych uczestników oraz gości i zaznaczył, że powstanie nowego wydziału było odpowiedzią na potrzeby zgłaszane przez przedstawicieli społeczności województwa lubuskiego i elementem rozwoju Alma Mater Lebusana. Wskazał, iż kształcenie prawników musi łączyć w sobie elementy wiedzy akademickiej i praktycznej, oraz że signum temporis nowoczesnego uniwersytetu jest umiędzynarodowienie, tak badań, jak procesu dydaktycznego. Wyraził także nadzieję, iż przedmiotowa konferencja stanie się polem wymiany doświadczeń i zarzewiem wypracowania możliwie najlepszego modelu kształcenia prawników, który będzie odpowiadał potrzebom krajowego rynku pracy oraz pozwoli odnaleźć się absolwentom w strukturach jednoczącej się Europy.

Poruszana podczas konferencji problematyka została pomieszczona w czterech sesjach, a w trakcie obrad dominował język angielski. Pierwszej, inauguracyjnej sesji przewodniczyła prof. dr hab. inż. Janina Stankiewicz, dziekan Wydziału Ekonomii i Zarządzania UZ.

Pierwszy referat na konferencji wygłosił prof. Rainer Arnold (Uniwersytet w Regensburgu), pt. Potrzeba internacjonalizacji edukacji prawniczej. W pierwszej kolejności prelegent odniósł się do zagadnienia związanego ze złożonością prawa, która prowadzi do złożoności jego stosowania. Taki stan rzeczy wynika m.in. z działań, które podejmowane są w płaszczyźnie unijnej. Chodzi tu oczywiście o zmiany w prawie, które mają bezpośrednie przełożenie w porządkach krajowych państw członkowskich. Wyzwanie to potrzebne jest także w szkolnictwie wyższym, które nie może być zorientowane tylko na prawo krajowe. Do osiągnięcia tego celu konieczna jest także znajomość zagranicznych systemów prawnych. Według prelegenta internacjonalizacja prawa oraz immanentnie związana $\mathrm{z}$ nią internacjonalizacja uniwersyteckiego kształcenia prawników rodzi potrzebę umiędzynarodowienia nie tylko treści nauczania i badań, ale także samej nauki. Jak podkreślił, istotny wpływ na proces internacjonalizacji edukacji prawniczej mają także programy takie jak Erasmus. Dotyczy to również nauczycieli, bowiem możliwość kształcenia ich za granicą jest warunkiem koniecznym do urzeczywistnienia tego procesu w nauczaniu. 
Jako drugi głos zabrał Christian Zens (kanclerz Europejskiego Uniwersytetu Viadrina we Frankfurcie nad Odrą), który przedstawił Model dualnego kształcenia prawników na Europejskim Uniwersytecie Viadrina. Prelegent wyjaśnił, iż taka forma kształcenia jest jedną z form kształcenia, które oferuje się w Europejskim Uniwersytecie Viadrina. Jest ona realizowana we współpracy z Uniwersytetem im. Adama Mickiewicza w Poznaniu i skierowana przede wszystkim do studentów niemieckich i polskich. Studentom umożliwia się poznanie systemów prawa niemieckiego i polskiego oraz uzyskanie dyplomów: magister prawa (polskiego), bachelor (LL.B) i master of german and polish law (LL.M.). Studia licencjackie (bachelor) obejmują 6 semestrów, w trakcie których w ramach 25 modułów realizowane są zagadnienia m.in. z zakresu prawa cywilnego, karnego, administracyjnego, międzynarodowego prywatnego, europejskiego, humanitarnego (prawo niemieckie) oraz prawa konstytucyjnego, cywilnego, karnego i historii prawa (prawo polskie). Ponadto studenci zobowiązani są przedstawić pracę licencjacką. Program magisterski składa się z 4 semestrów, obejmujących 10 modułów, w tym pracę magisterską, które służą pogłębieniu wiedzy o prawie polskim i niemieckim. Prelegent podniósł także, iż niezależnie od toczącej się w Niemczech dyskusji dotyczącej relacji między egzaminem państwowym a programem studiów zwiększenie różnorodności modeli kształcenia prawników powinno być postrzegane jako szansa dla studentów i dla uniwersytetów.

Kolejny z prelegentów, prof. dr hab. Pasquale Policastro (Uniwersytet Szczeciński), w referacie pt. Jakie wykształcenie dla europejskiego prawni$k a$ na podstawie doświadczenia MasterEu oraz propozycji Menu for Justice podkreślił, że Unia Europejska zbudowana jest na podwalinie wspólnych wartości i że u jej podstaw leży wspólna kultura prawna. Pogłębiająca się integracja powoduje konieczność wykształcenia nowego pokolenia prawników, którzy będą w stanie stawić czoła wyzwaniom wspólnej przestrzeni prawnej. Realizacja tego postulatu wymaga dokonania krytycznego przeglądu rozwiązań funkcjonujących w państwach członkowskich, w szczególności monitorowania programów kształcenia akademickiego i zawodowego w odniesieniu do studiów prawniczych, analizy treści i metod kształcenia, sposobów walidacji na różnych etapach edukacji, włączania określonych treści w szkolenia pracowników wymiaru sprawiedliwości. Działania te mają przyczynić się do wypracowania wspólnych europejskich standardów możli- 
wych do zrealizowania w państwach UE, przy jednoczesnym poszanowaniu krajowych rozwiązań dotyczących systemu sprawiedliwości, administracji i szkolnictwa wyższego.

W wystąpieniu zatytułowanym Refleksje dotyczące egzaminów na aplikację adwokackq mec. Sławomir Krześ (wicedziekan Okręgowej Rady Adwokackiej we Wrocławiu) zwrócił uwagę na wpływ, jaki ma uczelnia w procesie przygotowania studentów zarówno do egzaminów wstępnych na aplikacje prawnicze, jak i do odbywania aplikacji. Wskazał, że potrzebne jest stworzenie takiego programu nauczania, by dominowały w nim przedmioty, które będą miały zastosowanie w praktyce zawodowej. W trakcie studiów student powinien prawidłowo opanować terminologię prawniczą, nabyć wiedzę na temat zasad obowiązujących w poszczególnych dziedzinach prawa, a także zostać przygotowany do samodzielnego rozwiązywania problemów prawnych. Ten ostatni cel realizowany ma być przy pomocy metody kazusowej. Ponadto zwrócił uwagę, że w procesie kształcenia należy położyć szczególny nacisk na współpracę z osobami przygotowującymi aplikantów do zawodu. Mając powyższe na względzie, mec. Sławomir Krześ zaznaczył, że podstawą pozytywnego wyniku egzaminu na aplikację jest solidna wiedza wyniesiona ze studiów.

Drugiej sesji przewodniczył prof. nadzw. dr hab. Zbysław Dobrowolski (Instytut Spraw Publicznych, Uniwersytet Jagielloński).

Problemy, z którymi borykają się uczelnie wyższe kształcące prawników, przedstawiła prof. UAM dr hab. Krystyna Wojtczak w referacie pt. Edukacja prawników w Polsce - ocena nowych rozwiązań. Na wstępie prelegentka nakreśliła rys historyczny kształcenia prawników w powojennej Polsce. Przypomniała, iż jednym z elementów demokratyzacji ustroju z przełomu lat $89 / 90$ były zmiany w regulacjach prawnych, które dały uczelniom wyższym szerszą autonomię w budowaniu programów nauczania i planów studiów. Następnie dokonała przeglądu prawnych podstaw kształcenia obowiązujących dla kierunku studiów prawo od lat 90. oraz zaprezentowała najnowsze, bo wprowadzone w 2014 r., pomysły ustawodawcy w przedmiotowej materii. Wskazała, iż studia dla kierunku prawo mają być prowadzone jedynie jako jednolite studia magisterskie, o profilu ogólnoakademickim lub o profilu praktycznym, a szkoły wyższe muszą stosownie do tego zmodyfikować programy i efekty kształcenia. Podniosła też zagadnienie kształce- 
nia pozaformalnego, tj. uznawania przez szkoły wyższe efektów kształcenia zdobytych w pracy zawodowej. Podsumowując, stwierdziła, iż wprowadzone zmiany są jedynie niedoskonałą odpowiedzią na pytania stawiane przez przedstawicieli środowisk prawniczych i akademickich o model wykształcenia prawnika.

Dr Piotr Mysiak (prodziekan Wydziału Prawa i Administracji UZ) w swoim wystąpieniu pt. Nowe spojrzenie na kształcenie prawników na Wydziale Prawa i Administracji Uniwersytetu Zielonogórskiego poruszył problematykę budowania programów studiów prawniczych. Prezentując program kształcenia studentów Wydziału Prawa i Administracji UZ, zaznaczył, iż aktualne tempo i skala zmian w prawie, będące następstwem działalności prawotwórczej umocowanych do tego organów państwa, muszą znaleźć odzwierciedlenie w obowiązującym modelu kształcenia na studiach prawniczych. To powoduje konieczność ograniczenia procesu wyłącznie nabywania i poszerzania wiedzy przez studenta na rzecz zdobywania przez niego umiejętności i tego, co Krajowe Ramy Kwalifikacji określają mianem kompetencji społecznych. Stąd w programie studiów, obok tradycyjnych wykładów i ćwiczeń, w większym stopniu zostały uwzględnione zajęcia mające na celu nabycie praktycznych umiejętności stosowania prawa. Takie ujęcie, jak zaznaczył prelegent, ma prowadzić do jak najlepszego przygotowania studentów do egzaminów na aplikację i w efekcie - do wykonywania tradycyjnych zawodów prawniczych, a jednocześnie nie wyklucza alternatywnych ścieżek kariery zawodowej.

Drugi dzień konferencji poprzedziła uroczysta inauguracja roku akademickiego Uniwersytetu Zielonogórskiego 2014/2015, w trakcie której wykład inauguracyjny poświęcony roli wspólnych wartości w procesie integracji europejskiej wygłosił prof. dr hab. Bogusław Banaszak. Następnie uczestnicy konferencji udali się na sesję, której przewodniczyli prof. Ioan Ganfalean (dziekan Wydziału Prawa w Alba Julii) i prof. Miruna Tudorascu (wicedziekan Wydziału Prawa w Alba Julii).

Na temat Edukacji prawniczej we Włoszech wypowiedział się prof. Luca Mezzetti (dyrektor Wyższej Szkoły Prawa Uniwersytetu w Bolonii). Podczas wystąpienia prelegent zwrócił uwagę, że we Włoszech, tak jak i w innych państwach członkowskich UE, obowiązują trzystopniowe studia, co jest efektem tzw. procesu bolońskiego. Pierwszy stopień trwa 3 lata i kończy się zdoby- 
ciem tytułu licencjata. Drugi stopień trwa 2 lata. Po tym czasie student uzyskuje tytuł magistra. Trzeci stopień kończy się uzyskaniem tytułu doktora. Zdaniem Profesora zmiany, które dokonały się na skutek procesu bolońskiego, dają studentom szeroki wachlarz możliwości. Bez większych przeszkód mogą oni bowiem studiować za granicą, gdzie zdobywają doświadczenie, ale także mają możliwość rozwoju umiejętności językowych połączonych z wiedzą specjalistyczną.

Kolejni uczestnicy konferencji, prof. Bernd Wieser (wicedziekan Wydziału Prawa Uniwersytetu w Graz) i prof. Armin Stolz (Uniwersytet w Graz), przedstawili Kształcenie prawników w Austrii. Studia prawnicze w ich kraju, choć zasadniczo wolne od opłat i nie ma na nie egzaminów wstępnych, należą do najbardziej tradycyjnych i prestiżowych studiów uniwersyteckich. W przeszłości osoba chcąca wykonywać jeden z tradycyjnych zawodów prawniczych musiała być doktorem prawa. Jedynie wyjątkowo akceptowano osoby nieposiadające takiego tytułu - stąd być może pewna niechęć i trudności z wprowadzeniem tzw. procesu bolońskiego. Prelegenci wskazali, że regulacje prawne dotyczące przedmiotowego zagadnienia pomieszczone są w przepisach pochodzących z 2002 r., ale programy nauczania uchwalane na poszczególnych wydziałach prawa mogą znacznie się różnić. Studia prawnicze na Uniwersytecie w Graz, których program został zmieniony w 2013 r. i obowiązuje od semestru zimowego 2014/2015, obejmują osiem semestrów, trzy sekcje (tzn. grupy przedmiotów), możliwość specjalizacji i pracę dyplomową. Studia kończą się uzyskaniem stopnia naukowego magistra (Magister der Rechtswissenschaften). Program studiów doktoranckich obejmuje dwa kolokwia doktorskie, trzy seminaria związane z przedmiotem specjalizacji oraz zaprezentowanie i obronę rozprawy doktorskiej.

W ostatnim wystąpieniu przewidzianym na dzień 1 października prof. Cristina Hermida del Llano (Universidad Rey Juan Carlos de Madrid) w referacie pt. Kształcenie prawników w Hiszpanii odniosła się do zagadnienia związanego z dostosowaniem hiszpańskich szkół wyższych do procesu bolońskiego. Prelegentka zwróciła uwagę, że hiszpańskie uniwersytety są obecnie dostosowywane do zmian, które wymagane są w ramach wskazanego procesu. Zdaniem prelegentki jest to czas znaczących przemian z tego względu, że reformy, które wdraża się dzięki procesowi bolońskiemu, mają przyczynić się do przygotowania studentów do rzeczywistości m.in. poprzez 
innowacyjne metody nauczania. Działania podejmowane w ramach tego procesu powinny przyczynić się do zwiększenia konkurencyjności europejskich uczelni wyższych.

Ostatni, trzeci dzień konferencji rozpoczęła inauguracja roku akademickiego Wydziału Prawa i Administracji UZ, w trakcie której wykład inauguracyjny dotyczący problematyki projektu konstytucji Rzeczypospolitej Polskiej przygotowanego przez Komisję Konstytucyjną Sejmu Rzeczypospolitej Polskiej i uchwalonego dnia 24 sierpnia 1991 r. wygłosił prof. dr hab. Janusz Trzciński (były prezes Naczelnego Sądu Administracyjnego i były wiceprezes Trybunału Konstytucyjnego).

Sesję naukową w tym dniu poprowadziła prof. Milanou Hrušakovou (dziekan Wydziału Prawa Uniwersytetu w Ołomuńcu).

Obrady rozpoczął prof. Christian von Bar (Uniwersytet w Osnabrück), który w wystąpieniu pt. Kształcenie prawników w Niemczech nakreślił obowiązujący tam model. Wskazał, iż studia prawnicze to jeden z nielicznych kierunków, w którym zachowano tradycyjny system jednolitości studiów, przy czym studia składają się z dwóch etapów kształcenia. W skład pierwszego etapu, tzw. studium podstawowego, wchodzą trzy kursy podstawowe, tj. prawa karnego, cywilnego i publicznego. Studium podstawowe kończą egzaminy i prace domowe. Następnie student rozpoczyna tzw. studium główne. Ponadto student wybiera specjalizację; jest to przykładowo prawo cywilne, prawo gospodarcze, prawo medialne lub prawo międzynarodowe. Regularny czas studiów prawniczych wynosi przynajmniej 5 lat i kończy się pierwszym egzaminem państwowym (1. Juristische Prüfung). Jednak w większości przypadków studenci poświęcają jeszcze dodatkowy rok na przygotowania do egzaminu. Pierwszy egzamin państwowy stanowi zarówno dyplom ukończenia studiów prawniczych, jak i zaświadczenie umożliwiające rozpoczęcie aplikacji prawniczej (Refendariat). Prelegent podkreślił, że od początku studiów ustawy są głównym narzędziem pracy każdego studenta, a nacisk kładziony jest na naukę ich stosowania w praktyce. Egzaminy wiążą się z dogłębną analizą przykładowych stanów faktycznych i polegają na napisaniu opinii prawnej, stosując daną ustawę.

Na temat Kształcenia prawników na Ukrainie wypowiedział się prof. Jurij Boshytskyi (rektor Kijowskiego Uniwersytetu Prawa Akademii Nauk Prawnych Ukrainy). Podniósł, iż jego uczelnia szczególną uwagę przywiązuje 
do zagwarantowania studentom odpowiedniej edukacji prawniczej powiązanej z praktyką. Celem jest kształcenie wysoko wykwalifikowanych specjalistów przez przekazywanie im rozległej wiedzy m.in. w zakresie prawa europejskiego, prawa zobowiązań, prawa własności intelektualnej, organizowanie różnego rodzaju szkoleń, prowadzenie badań naukowych z różnych dziedzin prawa, jak i prowadzenie współpracy z partnerami zagranicznymi. Ponadto prelegent zwrócił uwagę, że Kijowski Uniwersytet Prawa aktywnie uczestniczy w organizowaniu konferencji zarówno międzynarodowych, jak i krajowych. Efekty działalności naukowo-badawczej tej uczelni widoczne są corocznie poprzez publikowanie wyników badań w monografiach, podręcznikach i czasopismach naukowych, które znajdują się w zbiorach biblioteki uniwersyteckiej i są dostępne dla studentów.

Profesor Milanou Hrušakovou (dziekan Wydziału Prawa Uniwersytetu w Ołomuńcu) i prof. Jiř́i Jirásek (Uniwersytet w Ołomuńcu) zaprezentowali Kształcenie prawników w Czechach. Podjęcie studiów prawniczych w Czechach wymaga pozytywnego przejścia postępowania rekrutacyjnego, zasadniczo w postaci rozmowy. Studia nie są płatne, niemniej przewidziane są opłaty m.in. za postępowanie kwalifikacyjne, za przekroczenie okresu studiowania oraz za studiowanie w języku obcym. Studia mogą być jednolite i wtedy kończą się uzyskaniem tytułu magistra (magistr), który jest tytułem zawodowym, lub dwustopniowe, tzn. zdobycie tytułu magistra poprzedza uzyskanie tytułu zawodowego licencjata (bakalar). Studia doktoranckie trwają 3 lata, kończą się egzaminem państwowym i publicznym przedstawieniem oraz obroną pracy doktorskiej, która musi zostać opublikowana.

Kolejne zagadnienie poruszone w tej sesji dotyczyło Kształcenia prawników w Rumunii. Prof. Miruna Tudorascu (prodziekan Wydziału Prawa w Alba Julii) i prof. Ioan Ganfalean (dziekan Wydziału Prawa w Alba Julii) na wstępie zwrócili uwagę, że prawo do nauki znajduje swoje odzwierciedlenie w art. 32 Konstytucji Rumunii. Szczególnie zaakcentowano ustęp pierwszy tej jednostki redakcyjnej aktu, zgodnie z którym: „Prawo do nauki zapewnione jest poprzez powszechne nauczanie obowiązkowe, szkolnictwo średnie ogólnokształcące i zawodowe, szkolnictwo wyższe, jak też poprzez inne formy kształcenia i doskonalenia”. Prelegenci zwrócili uwagę na działania, jakie podjęto w celu dostosowania edukacji rumuńskiej do standardów przyjętych w Unii Europejskiej. Wskazali, że wszelkie podejmowane 
w tym kierunku przedsięwzięcia rozpoczęły się od zmian w krajowych przepisach prawa związanych z zawodami prawniczymi. Wskazali, że w związku z wdrożeniem systemu bolońskiego w Rumunii studenci mają możliwość ukończenia czteroletnich studiów licencjackich (studia I stopnia) i rocznych studiów magisterskich (studia II stopnia). Studenci mają więc możliwość ukończenia studiów licencjackich, magisterskich oraz doktoranckich na Wydziale Prawa. Mogą także przystąpić do egzaminów na określoną aplikację. Zaznaczyli, że obecnie największym zainteresowaniem w Rumunii cieszy się Narodowy Instytut Sądownictwa, który przygotowuje do zawodu sędziów i prokuratorów.

Dr Joanna Osiejewicz (Wydział Prawa i Administracji UZ) przedstawiła referat dotyczący Konieczności edukacji prawniczej tłumaczy sądowych i ttumaczy przysięgłych w świetle dyrektywy 2010/64/UE w sprawie prawa do thumaczenia ustnego i ttumaczenia pisemnego $w$ postępowaniu karnym. Prelegentka odniosła się w nim przede wszystkim do prawa do tłumaczenia ustnego i pisemnego, wiedzy prawniczej, jako podstawowego czynnika dla interpretacji prawnej i tłumaczenia oraz zharmonizowania edukacji prawniczej. W ramach tych zagadnień poruszyła kwestie dotyczące programu sztokholmskiego, który promuje prawa podstawowe zapisane w Karcie praw podstawowych Unii Europejskiej i Europejskiej konwencji o ochronie praw człowieka i podstawowych wolności, a zwłaszcza prawo do rzetelnego procesu sądowego, które przejawia się w korzystaniu przez oskarżonego z bezpłatnej pomocy tłumacza, jeżeli nie rozumie lub nie mówi językiem używanym w sądzie. Przedstawiła także główne założenia dyrektywy 2010/64/UE, do których zalicza się m.in. poprawę ochrony praw jednostki poprzez rozwój wspólnych minimalnych zasad dotyczących prawa do rzetelnego procesu sądowego, konieczność zagwarantowania odpowiedniej jakości tłumaczenia, która jest wystarczająca do zagwarantowania rzetelności postępowania, w szczególności poprzez zapewnienie, aby podejrzani lub oskarżeni zrozumieli zarzuty i dowody przeciwko nim oraz byli w stanie wykonywać swoje prawo do obrony. Ponadto podczas wystąpienia zwrócono uwagę na wymagania, jakie są stawiane tłumaczom przysięgłym.

Należy też wspomnieć, iż każdy dzień obrad kończyły dyskusje, które były polem wymiany doświadczeń i, po części, krytycznej oceny funkcjonujących rozwiązań oraz artykulacji trudności, z którymi borykają się szko- 
ły wyższe kształcące prawników. Uczestnicy konferencji podkreślali przede wszystkim wielość rozwiązań dotyczących modelu edukacji prawników w państwach Unii Europejskiej, odmienności dotyczące mechanizmu uzyskiwania stopni naukowych i zawodowych, a nawet różnice dotyczące takich kwestii, jak relacje studentów z kadrą akademicką i organizacja roku akademickiego. Zwrócono uwagę, iż taka sytuacja utrudnia wymianę studentów, nie sprzyja wymianie kadr naukowych i umiędzynarodowieniu procesu dydaktycznego. Wskazano, iż trudności w realizacji tzw. procesu bolońskiego, zwłaszcza w odniesieniu do jednolitych studiów magisterskich, oraz specyfika rozwiązań prawnych występujących w poszczególnych państwach nie pozwalają na wniosek, iż możliwa jest stosunkowo szybka likwidacja różnic w kształceniu prawników w poszczególnych państwach i wypracowanie w tym obszarze wspólnego modelu.

Zamknięcia i podsumowania konferencji dokonał prof. dr hab. Bogusław Banaszak, który serdecznie podziękował gościom oraz uczestnikom za trud przybycia i aktywny udział w konferencji. Stwierdził, iz przebieg obrad tylko utwierdził go w przekonaniu o tym, jak aktualna i istotna jest podniesiona problematyka, nie tylko dla środowisk akademickich zajmujących się kształceniem prawników, ale także dla tych wszystkich, którzy w przyszłości będą związani ze stosowaniem i stanowieniem prawa w warunkach pogłębiającej się integracji europejskiej. Ponadto zapowiedział publikację wystąpień prelegentów w formie pracy zwartej.

Anna Feja-Paszkiewicz

Justyna Węgrzyn

Uniwersytet Zielonogórski 